Association for Information Systems AIS Electronic Library (AISeL)

AMCIS 1997 Proceedings

Americas Conference on Information Systems

(AMCIS)

8-15-1997

\title{
Creating Customer Focused Processes at Barnett Bank
}

David Paper

Utah State University

Ganesh D. Bhatt

Austin Peay State University

James A. Rodger

University of Pittsburgh at Johnstown

Follow this and additional works at: http://aisel.aisnet.org/amcis1997

\section{Recommended Citation}

Paper, David; Bhatt, Ganesh D.; and Rodger, James A., "Creating Customer Focused Processes at Barnett Bank" (1997). AMCIS 1997 Proceedings. 87.

http://aisel.aisnet.org/amcis1997/87

This material is brought to you by the Americas Conference on Information Systems (AMCIS) at AIS Electronic Library (AISeL). It has been accepted for inclusion in AMCIS 1997 Proceedings by an authorized administrator of AIS Electronic Library (AISeL). For more information, please contact elibrary@aisnet.org. 


\title{
Creating Customer Focused Processes at Barnett Bank
}

\author{
David Paper (contact person) \\ Utah State University \\ Ganesh D. Bhatt \\ Austin Peay State University \\ James A. Rodger \\ University of Pittsburgh at Johnstown
}

\section{BPR Initiatives at Barnett}

In recent years, the banking industry has seen many changes. Two decades ago, customers did not have many shopping options for checking and savings accounts, automobile loans, insurance, credit cards, mortgage loans, and stocks and bonds. Today, banks, insurance companies, mortgage companies, credit card firms, and other financial companies are competing for customers in the multi-billion dollar financial services industry.

To increase its competitive position, Barnett Bank opted to redesign and improve its business processes. The strategic goal of BPR was to offer services that are valuable to its customers. The bank has coined the term "value propositions" as an enterprise-wide tactic to communicate the corporate goal of providing value by meeting the needs of each and every oneof its customers. Hence, employees in all functional areas and all levels ofthe organization have a shared goal of doing whatever it takes to make theirservices valuable to the customer. Value propositions focus on increasing the quality of service and delivery of financial products and to reduce the processing time of customer requests.

Since Barnett didn't want to make dramatic changes in its business operationswithout involving employees at all levels of the organization, it used a dualstrategy. The dual strategy consisted of incremental process improvement coupled with BPR.

Incremental improvement projects focus employees on making adjustments to existing business processes. The bank found that incremental improvement projects were very important to the overall reengineering effort because they give employees experience in dealing with change. Incremental improvement projects included updating computer programs to process loans more effectively, building user-friendly graphical user interfaces for systems to provide business executives easier access to the data they require for creating value propositions for bank customers, and creating new financial instruments. All of these incremental change projects and many others were introduced on top of regular employee duties to sensitize employees to the upcoming, more dramatic changes associated with BPR. In addition, the incremental strategy included only projects that could be aligned with the Barnett business and BPR strategy and that had the potential to add value to customer propositions.

BPR focused on radical redesign core business processes. The major project underway at the time of the interviews was redesign of the entire consumer lending function. Redesign of this function impacted hundreds of employees and crossed functional boundaries. Therefore, Barnett thought it prudent to combine incremental and radical process improvement into its overall BPR strategy. Radical change is very difficult for most people to deal with, but continuous involvement in process improvement helped make change a way of life at the bank.

Although the initial results of the dual strategy have been promising, Hammer and Champy (1993) argue that BPR is a radical change strategy as opposed to an incremental improvement change strategy. However, our results suggest that a combination of radical and incremental process improvement has the potential to add value to the organization as well as acclimate employees to an environment of change.

Barnett believes in the power of IT to shape business process change. It also believes that BPR initiatives shape IT change. The role of IT as an enabler to BPR cannot be ignored because in many cases it is almost 
impossible to streamline and restructure a process without the assistance of technology. On the other hand, business process change focuses on creating customer value and cannot be constrained by the IT configuration. Redundancies, overlap, and local databases are examples that show how IT can become a constraint in providing accurate and timely services to customers even with well- intentioned BPR efforts. Therefore, the bank has made it a priority to parallel BPR with radical changes in the way data is stored, distributed, and processed.

Contrary to most of the popular literature, the interviews reflected a consistent theme about the urgency of redesigning information systems and business processes simultaneously. The literature tends to push IT as the enabler of BPR or BPR as the central focus with IT as a supporting tool. Our research with Barnett suggested that successful BPR can be a two-pronged operation business redesign and IT redesign as part of a more comprehensive strategy of BPR. Business redesign encompasses radically changing business processes. IT redesign encompasses radically changing data and IT configurations to better support business processes. Both of these efforts share the goal of creating value for the customer.

\section{Propositions Generated From The Case}

The Barnett Bank study provided many insights into how a company actually deals with BPR on an enterprise-wide basis. A synthesis of the interviews and observations led us to develop a set of propositions which could tested against other organizations involved in BPR. The propositions are also intended as nongeneralizable guidelines for other organizations involved or considering becoming involved in BPR.

\section{Proposition 1.}

A dual approach of radical and incremental process improvement is more likely to be successful than only radical improvement approach. Incremental improvement offers a mechanism to get employees involved in change projects in smaller chunks and allows them to become sensitized to working in an environment of change.

\section{Proposition 2.}

Bringing experienced business managers into the Technology Department increases the chances that systems development projects are aligned with business goals. There is no substitute for business experience. As one business manager described, "It is much easier to learn about technology than it is about business. It took me 6 months to learn COBOL, but 10 years to learn the banking business".

\section{Proposition 3.}

In information intensive industries such as banking and insurance, redesign of the IT infrastructure should accompany BPR because information flow is lifeblood of such organizations. Barnett Bank realized that redesign of DCL in isolation of IT would not yield sufficient reductions in loan processing time. IT is a powerful tool that can greatly expedite information processing if the IT architecture is aligned with the business processes it is trying to support.

\section{Proposition 4.}

Basing BPR on a sound business need should greatly increase its chances of success. Barnett chose to redesign DCL because it was concerned about its reputation with its customers. Prior to DCL reengineering, loan processing cycle time was approximately three days. Long cycle times translate into poor customer response. Since Barnett is now trying to compete in the financial services industry, it felt that it needed an edge. Barnett believes that BPR will give them that edge by decreasing cycle times and improving information sharing. Data were not made available on how much cycle time has been reduced, but bank executives informed us that BPR has paid off quite well. 


\section{Proposition 5.}

Since information sharing is the key to enterprise-wide communication, the Technology Department should lead the BPR effort. Information is used by all functional areas across the bank. Since the Technology Department manages the information resources of the entire company, it is in an ideal position to lead. In addition, the Technology Department is charged with maintaining existing systems and developing new systems that serve the needs of the business.

\section{Proposition 6.}

Visible and continuous support from top management should greatly increase the chances of BPR success. If top management does not visibly support BPR, politics will destroy the project. Most people are afraid of change. If given the opportunity to resist change, many will do it. Moreover, changing the way business is conducted will not be tolerated without top-level approval because top management is in charge of the business. If those involved in the process are not part of the project, they will resist changes and, most likely, sabotage the BPR effort. After all, they are the ones who will most likely be impacted by the changes.

\section{Proposition 7.}

Choosing a BPR project that must work should increase its chances of success. Success is hard to resist. If a project is very successful, it will be much easier to get organizational buy-in. The DCL project had to work. DCL processing was taking too long and was negatively impacting customer response time. Therefore, Barnett felt that it had to take action. It decided to embark on a major BPR project to rethink DCL from 32 to 2 processing offices. Reengineering a critical process was a risky venture, but Barnett believed that it had no choice. Since the project had to succeed, the risk wasn't as much of a concern as the potential for excellent results.

\section{Final Thoughts}

Consistent with the literature, case study research should be the initial research methodology to study phenomenon in dynamic and complex settings (Eisenhardt, 1989; Yin, 1989). In business settings, we cannot administrate controlled experiments. We can only hope to observe businesses in action and ask them questions about how what they do and how they do it. We consider survey research a useful tool, but only after

patterns have been established via rich data collection methodologies like case studies. We hope that our study acts as a vehicle to stimulate additional in-depth research in the area of BPR.

From a theoretical perspective, our study contradicts the popular views that business redesign drives IT redesign or IT redesign drives business redesign. We found that business and IT redesign go hand-in-hand. Information is part of the business process. Information helps make the business process work more effectively. Whether an organization builds a product or provides a service, information enables people to communicate effectively across the process path. Quality information also helps managers make more timely and accurate decisions. To ensure delivery of quality information, information systems development should be synchronized to the business processes it supports and flexible enough to accommodate changes.

Barnett devised a clever way to help align BPR with IT redesign. The Technology Department was populated with experienced bank managers to help align existing and future systems development with business objectives, business process changes, and customer value propositions. To facilitate data integration and information sharing the Technology Department moved to a data warehousing schema. Data warehousing enabled the bank to centralize critical data to ensure integrity and quality. At the same time, the data warehouse allows distributed processing because local departments can obtain data in a variety of languages and data structures. 
Our study also contradicts the popular separation of radical and incremental improvement. Barnett employed a dual strategy of BPR. It used incremental process improvement projects to sensitize employees to work in an environment of change. As radical redesign was taking place, workers gained experience and confidence working on smaller improvement projects. In other words, incremental projects made employees feel a part of the larger BPR initiative. Process transformation is a continuous activity that takes time to work. Continuous exposure to change made it a daily part of their work.

\section{References}

Davenport, T.H. \& Short, J.E. (1990) The New Industrial Engineering: Information Technology and Business Process Redesign. Sloan Management Review, Summer, 11-27.

Davenport, T.H. (1993) Process Innovation: Reengineering Work Through Information Technology. Harvard Business Press, Boston, Massachusetts.

Eisenhardt, K.M. (1989) Building Theories from Case Study Research. Academy of Management Review, $14,532-550$

Hammer, M. (1990) Reengineering Work: Don't Automate, Obliterate. Harvard Business Review, JulyAugust, 18-25.

Hammer, M. \& Champy, J. (1993) Reengineering the Corporation. Harper Collins Books, New York, NY.

Yin, R.K. (1989) Case Study Research: Design and Methods. Sage Publications, London. 